\section{NOTIFICATION OF TUBERCULOSIS, COMPARED WITH THE REPORTED DEATES FROM THIS DISEASE.}

By G. Lissant Cox, M.D. Camb.,

OENTRAL TURERCULOSIS OFFICER, COUNTY OF IANCASTER.

AT the present time considerable attention is heing drawn to the unknown infective cases of tuberculosis which exist in all areas. It is generally ayreed that the "known" consumptive is a much less dangerous person than the unknown, and also that, during the later stages of tuberculosis of the lungs, the largest number of the infertive agent-the tubercle barilli-is set free, so that each advanced case is more dangerous as a source of infection than an early one. If, therefore, as is the case at present, persons suffering from pulmonary tuberculosis are never notified, and die from the disease; and if, as is also often the case, notification is only made in the last stages of the disease the attempts to combat the disease can only be partial and incompiete.

In the administrative county of Iancaster during the five years $1916-20$ a very careful scritiny has been made of all deaths from tuberculosis not notified under the Tuberculosis Regulations, and further, during a part of 1926 and 1921 , a specia! inquiry was made into the reasons for non-notification in 163 consecutive cases. A summary of the results of this inquiry is given later in this article.

'The total number of deaths from tuberculosis in the year ended Dee. 31st, 1920, and during the four preceding yearc, of persons nol notified is given in Table J.

\section{TABLE I.-Deaths from Tuberculosis of Cases} not Notified.

\begin{tabular}{|c|c|c|c|c|c|c|c|}
\hline & & & Pulmon & Non & puln & nary. & 'Total \\
\hline 1920 & . & & .. 177 & $\cdots$ & 122 & $\ldots \ldots$ & 299 \\
\hline 1919 & . & . & 221 & & 104 & & 325 \\
\hline 1918 & . & . . & 303 & & 137 & . & 440 \\
\hline 1917 & . & . & 256 & $\cdots$ & 141 & & 397 \\
\hline 916 & & . & 270 & $\ldots \ldots$ & 147 & $\cdots$ & 417 \\
\hline
\end{tabular}

-The particulars of each death from tuberculosis have been carefully scrutinised in the public health department, so that, as far as possible, all deaths that do not properly belong to the administrative county have been excluded from these figures. Further, by arrangement, local registrars of deaths forward details of all deaths from tuberculosis, and these have been compared with the case notifications, enabling the particulars following to be obtained.

Three objects are serred by a notification of a case of tuberculosis. First, the local public health authority is made aware of what may be, or will be, a case of infectious disease, and through the information received, will be in a position to deal with the same. Second, the person comes under the county special organisation dealing with the disease, and can then receive the advice and assistance of the tuberculosis officer, and such treatment as may be recommended will be viven under the county scheme. Third, the examination of "contacts" is made possible, whereby early or other cases are discovered and may receive appropriate treatment. The 1920 figures are analysed in Table II.

Is the total deaths in the administrative county in 1920 from pulmonary tuberculosis numbered 1323, the 177 non-notified fatal cases amounted to 13 per cent., as compared with 16 per cent. last year, 18 per cent. in 1918, and 16 per cent. in each of the years 1917 and 1916. It is satisfactory to note a decline in 1920 in the number of these non-notified fatal cases in the aggregate and in the percentage to the total pulmonary deaths.

There were also 375 deaths recorded in 1920 of persons notified as suffering from pulmonary tuberculosis which took place within three months of the date of notification.
TABI, IT.-Denths from Tuberculosis in 1920 of Cases not I'reviously Notified.

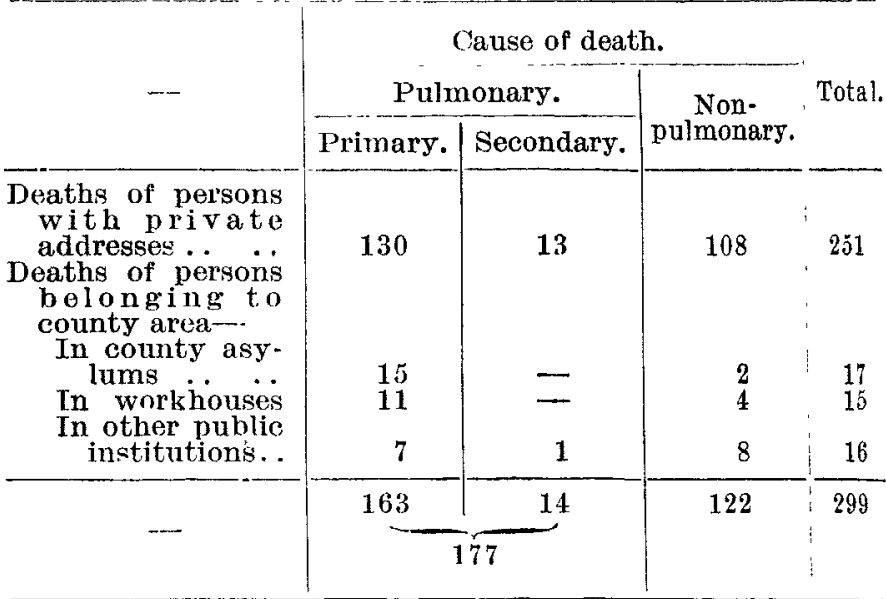

Special Inquiry into 105 Deaths from Tuberculosis of Cases not Previously Notified.

As under the Public Health (Tuberculosis) Regula. tions, 1912, a medical practitioner is required to notify every case of tuberculosis to the local medical officer of health within 48 hours of diagnosis, it is important to ascertain the circumstances under which notification comes to be omitted. A period was taken extending from Oct. 11th, 1920, to June 30th, 1921, and during this time 163 of such deaths were recorded-80 pulmonary and 83 non-pulmonary. Of this number 58 occurred in public institutions, leaving for inquiry 105 deaths - 45 pulmonary and 60 non-pulmonary. The result of the inquiries into the reasons for the non-notification of these 105 cases is shown in the following table :-

TABLE III.-Circumstances of Non-Notification of Fatal Cases.

\begin{tabular}{|c|c|c|c|}
\hline \multirow{2}{*}{-} & \multicolumn{2}{|c|}{ Cause of death. } & \multirow{2}{*}{$\begin{array}{l}\text { Total } \\
\text { deaths. }\end{array}$} \\
\hline & $\begin{array}{l}\text { Pul- } \\
\text { monary. }\end{array}$ & $\begin{array}{l}\text { Non-pul- } \\
\text { monary. }\end{array}$ & \\
\hline $\begin{array}{l}\text { Doctor in attendance shortly before } \\
\text { death- }\end{array}$ & & & \\
\hline $\begin{array}{cccc}1 \text { week or less } & \ldots & \ldots & \ldots \\
1 \text { to } 2 \text { weeks } & \ldots & \ldots & \ldots \\
2 \text { to } 3 \text { weeks } & \ldots & \ldots & \end{array}$ & $\begin{array}{l}3 \\
2 \\
\end{array}$ & $\begin{array}{l}8 \\
8 \\
3\end{array}$ & 24 \\
\hline $\begin{array}{l}\text { Misinterpretation of Tuberculosis } \\
\text { Regulations and notification be- }\end{array}$ & & & \\
\hline $\begin{array}{c}\text { lieved unnecessary } \\
\text { Cases previously notified in } \\
\text { another area.. }\end{array}$ & 5 & 1 & \\
\hline $\begin{array}{l}\text { Disease of long duration prior } \\
\text { to compulsory notification. }\end{array}$ & 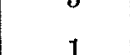 & 1 & \\
\hline Temporary resident $\ldots$ & $\stackrel{1}{-}$ & $\overline{1}$ & 16 \\
\hline $\begin{array}{ccc}\text { Cases known to tuberculosis } \\
\text { officers* }\end{array}$ & 7 & 1 & \\
\hline $\begin{array}{l}\text { Attended by more than one doctor } \\
\text { and notification believed to have }\end{array}$ & 8 & $i$ & \\
\hline been made by first practitioner. & 9 & 8 & 17 \\
\hline $\begin{array}{l}\text { Complicated cases presenting diffi- } \\
\text { culty in diagnosis }\end{array}$ & 6 & 19 & \\
\hline Accidental omission to notify $\quad \ldots$ & $\begin{array}{l}6 \\
5\end{array}$ & $\begin{array}{r}19 \\
7\end{array}$ & $1 ?$ \\
\hline No apparent reason for non- & & & \\
\hline $\begin{array}{l}\text { notification } \\
\text { Information not ascertained } \dot{\phi} \dagger \quad \cdots\end{array}$ & $\frac{4}{3}$ & $\underline{4}$ & $\begin{array}{l}8 \\
3\end{array}$ \\
\hline 一 & 45 & 60 & 105 \\
\hline
\end{tabular}

* Considerable doubt as to diagnosis in some of these cases. $\uparrow$ No reply received to inquiries.

\section{Summary and Conclusions.}

1. Amongst an estimated population of $1,730,929 \mathrm{in}$ the administrative county of Lancaster, the number of deaths from tuberculosis in 1920 was $1719-$ pulmonary 1323, non-pulmonary 396.

2. The notifications of pulmonary tuberculosis numbered 2084, and non-pulmonary tuberculosis 968 . About 70 per cent. of all new cases in 1920 were examined by the county tuberculosis officers prior to notification, these patients being sent for an opinion as to diagnosis and treatment.

3 . The deaths from pulmonary tuberculosis not notified were, in 1920,177 , and non-pulmonary 122. 
The deaths from pulmonary tuberculosis within three months of notification were 357 .

4. A special inquiry into 163 consecutive deaths not notified under the Regulations has shown: $(a)$ That a large proportion (58) occurred in public institutions ; (b) that many of the non-pulmonary cases were those of meningitis or specially complicated cases; $(c)$ that in the 45 pulmonary cases, 22 (practically half) were not notified owing to a misunderstanding of the Tuberculosis Regulations, or to a belief that the case had already been notified. The Regulations direct in Article $V$. that a practitioner "shall not notify a case ... if he has reasonable grounds for believing that the case has already been notified ... to the medical officer of health for the district within which the place of residence of the person is situate" ; and with the continuance of this clause-which at the most presents a rather unsatisfactory qualification as to notification-misunderstandings are almost certain to arise. No doubt the clause was inserted in an endeavour to avoid duplicate notifications in the same sanitary district, but in view of the liability of error, it would appear much more satisfactory to eliminate the qualification quoted above from the Regulations.

\section{MEDICINE AND THE LAW.}

\section{The Definition of Live Birth.}

AT the opening meeting of the Sheffield MedicoChirurgical Society on Oct. 13th Dr. Godfrey Carter delivered the presidential address, taking as his subject an analysis of his last 100 post-mortem examinations. One of the topics dealt with in the address was the definition of live birth as laid down in courts of law when a mother is tried for the miurder of her newlyborn child. The point criticised was the necessity of proof that every portion of the child had been extruded when the act.causing the death was performed, independently of whether breathing, movements, or other sign of life had occurred. The opinion of those present was that the birth should be treated as a live birth where, in other respects than that of complete delivery, the live birth of a full-term child has taken place, and where there is only evidence of an act of violence to which death can be attributed. A suggestion was made that an Act of Parliament should provide that "a child delivered at full-term and found upon medical examination to be healthy and free from any ascertainable cause of natural death, should be deemed to have been born alive, failing proof to the contrary.' This, of course, would take part of the onus of proof from any prosecution for murder, and would lay it upon the accused person, and in other respects could not be carried out by the authority of any judge or judges. The principle of making the prosecution prove the case against the prisoner is too firmly established in our criminal law for it to be likely that Parliament would sanction departure from it in such a case. Apart from this, however, the test of complete extrusion from the mother might be considered and dealt with. If this test were abolished, and the result adrocated by the Sheffield Medico-Chirurgical Society were attained, it would follow that many women and girls who are now convicted of concealment of birth would be convicted of murder or manslaughter. This in short, is what was desired at the meeting referred to. To medical men who have examined the bodies of infants killed in the usual circumstances of such cases, it is clear, as a rule, when one of those felonies bas been committed. It equally appears to them that such destruction of life ought to be punished severely and that punishment might check a certain wastage of human life, a result desirable in the interest of the nation. On the other hand, a verdict of murder entails the passing of the death sentence, and it is undesirable that this should be otherwise. A death sentence, however, in the case of nine out of ten of the mothers whose case is under consideration would neren be carried out and would be a futile formality.
A verdict of inanslaughter would impose almost necessarily on the judge the obligation to pass a severe sentence. Either of these verdicts and their consequences would be contrary to public feeling, and would tend to rouse even more sympathy for the criminal than is now exhibited, whenever such trials take place. Moreover, the jury must find a prisoner guilty before sentence is passed, and modern experience agrees with that of bygone generations that where the sentence entailed is heavier than public opinion approves, juries refuse to convict. In these circumstances, whatever may be the strictly logical inference to be drawn from the conditions provable by medical men in the cases referred to it, it appears unlikely that the law will be altered, or that if altered, very different verdicts from those "merciful verdicts" now returned would ensue. The points suggested should always be weighed in connexion with this subject.

\section{Action for Damages against a Medical Man.}

A case of considerable importance to general practitioners has just been decided at the Suffolk County Assizes, where a patient brought an action for negligence against Dr. H. G. Wood-Hill, a well-known medical man of Beccles, and obtained heavy damages. The patient, while driving a dog-cart was thrown out and sustained an injury to her right leg. Dr. Wood-Hill was sent for and diagnosed a fracture of the upper third of the femur. He treated her by a Thomas splint and extension, and had her removed to the Beccles Hospital, where she was also examined by his partner, Dr. G. R. Fox, who agreed both as to the diagnosis and treatment, and did not consider that an anæsthetic was advisable. No radiograph was taken, and it came out that the $X$ ray apparatus at the Beccles Hospital was out of order. The splint was removed and the weight taken away about five weeks after the accident, and Dr. Wood-Hill stated that he then found union to have taken place with only half an inch of shortening. He warned the patient against putting any weight on the leg for some time, and allowed her to go home to Hertfordshire about a fortnight later. Ten days after her return home she suddenly felt her leg give way. Dr. Cooper, her family doctor, was called in and he stated in his evidence that he found the right leg one and threequarter inches shorter than the other, with pain, swelling of the buttock, and inability to raise the leg. $\mathrm{He}$ diagnosed the fracture to be in the neck of the femur, and advised an $\mathrm{X}$ ray examination, which confirmed his opinion. The patient was subsequently removed to the Freemasons' Hospital in London, where an operation was performed.

There was a marked divergence of opinion among the surgeons examined. While Dr. Cooper stated that the fracture was in the neck of the femur, and gave it as his opinion that an anæsthetic should have been employed at first, Sir Hamilton Ballance said that he thought an anæesthetic was not indicated, as any struggling would have increased the damage round the fracture. He believed that a re-fracture of the bone had occurred, owing to the patient putting too much weight on it, and expressed himself as satisfied with Dr. Wood-Hill's treatment. Mr. Hugh Ernest Griffiths and Mr. Harold William Wilson, assistant surgeons at St. Bartholomew's Hospital, confirmed Sir Hamilton Ballance's opinion.

The verdict of the jury was largely influenced by Dr. Wood-Hill's omission to have an X ray photograph taken of the injury, and the lesson of the case is that in such positions this aid to diagnosis should not be omitted.

UNIVERSITY OF MANCHESTER.-Mr. Stanley Wyatt, M.Sc., investigator to the Industrial Fatigue Research Board, has been appointed Special Lecturer in Psychology; Dr. D. E. Core, Lecturer in Neurology; Dr. A. E. Barclay, Lecturer in Radiology ; and Mr. H. H. Rayner, Lecturer in the Surgical Diseases of Children. The following awards have been made: Leech Fellowships in Medicine, Dr, F. R. Ferguson and Dr. Eugenia R. A. Cooper. Graduate Scholarship in Medicine, Dr. G. V. Ashcroft ; Tom Jones Memorial Surgical Scholarship, A. H. Southam. 